\title{
Blurred lines: comparing room rates, star-ratings, and user-generated contents for full-service and select-service hotels
}

\author{
Amanda Belarmino ${ }^{1}$ Yoon Koh ${ }^{2}\left[\right.$ ] Hyejo Hailey Shin ${ }^{3}$
}

Received: 16 November 2020 / Accepted: 25 December 2021 / Published online: 11 February 2022

(c) The Author(s), under exclusive licence to Springer-Verlag GmbH Germany, part of Springer Nature 2022

\begin{abstract}
The relatively low cost to build select-service hotels coupled with increased competition in this segment has led to innovations that may have blurred the lines between full-service and select-service hotels. This study compares consumer perceptions of select-service and full-service hotels by comparing the best available rates and consumer-generated reviews from two sets of full-service and select-service hotels from Intercontinental Hotel Group and Hilton. This study found that brand, not segment, affected room rate while select-service hotels had significantly higher star-ratings than full-service hotels. For revenue managers, this study indicates that consumers are willing-to-pay a premium for hotels in certain brands.
\end{abstract}

Keywords Segmentation theory $\cdot$ Select-service $\cdot$ Full-service $\cdot$ Brand extensions · User-generated content

Yoon Koh

ykoh@uh.edu

Amanda Belarmino

amanda.belarmino@unlv.edu

Hyejo Hailey Shin

hailey.shin@polyu.edu.hk

1 William F. Harrah College of Hospitality Management, University of Nevada Las Vegas, 4505

S. Maryland Parkway, Suite 351, Las Vegas, NV 89154, USA

2 Conrad N. Hilton College of Hotel and Restaurant Management, University of Houston, 4450 University Drive, Suite 236, Houston, TX 77204, USA

3 School of Hotel and Tourism Management, Hong Kong Polytechnic University, 17 Science Museum Rd, TH 619, TST East, Kowloon, Hong Kong 


\section{Introduction}

Select-service hotels, properties with limited food and beverage service, no concierge or bell/valet staff, and limited meeting space, are the fastest growing segment of the hotel industry (Grigg 2019). Lodging companies continue to add services to differentiate new select-service brands ( $\mathrm{Su}$ and Reynolds 2019). The latest trend in this segment has been the creation of midscale and upper-midscale lifestyle select-service brands. In $2019,75 \%$ of all new hotel rooms were in the select-service segment, with select service hotels growing at a faster rate than the general lodging market (Hoisington 2019). Caption by Hyatt, launched in 2019, focused on sustainability and large social spaces while Accor's select-service Greet focused on up-cycled furniture and locally sourced food (Kubacki 2019). As lodging companies face an uncertain future after the COVID-19 pandemic, select-service properties are more likely to be built than their full-service counterparts (Wroten 2020). As these new brands are launched, lodging companies strive to differentiate each brand from their existing brands and from different segments. The line between select-service and full-service brands, however, has become blurred with the addition of amenities such as two-meal restaurants at Courtyard by Marriott (Yapp 2015).

Previous research found that guests in select-service hotels were more price sensitive whereas guests with high brand attachment tend to stay at full-service hotels (Tanford et al. 2012); indeed this is the only study to date that compares these segments. While the customer perception may be that select-service hotels are less expensive (Yapp 2015), the hotels may not be truly cheaper. However, increasingly high profile marketing of select-service brands like the Hampton Inn and the increase in lifestyle select-service brands lie Vib by Best Western are designed to increase emotional attachment to these select-service brands. While consumers view full-service hotels as more exciting, their brand images are less distinct and harder to imagine than brand images for select-service hotels (Su and Reynolds 2019). Investigations of pricing in select-service hotels have been limited to analyzing the accounting procedures and marketing theory behind revenue management (Mattimoe and Seal 2011), and comparing the end value of room rates (i.e. 0.00 or 0.99) for full-service and select-service hotels (Collins and Parsa 2006).

While researchers have examined how customers' brand attachment affects customers' evaluation of services toward a certain hotel brand (e.g. Rosli et al. 2020), not much has been investigated about its impact on purchase intention regardless of hotels' pricing and market segment. While full-service guests are more likely to be members of loyalty programs and have a higher switching cost (Tanford et al. 2012), prior research did not account for the fast-growing segment of select-services. Accordingly, this paper aims to investigate whether the price is indeed a determining factor between full-service hotels and select-service hotels. The current study also seeks to answer whether customers' evaluation of service attributes is different if pricing was not a determining factor between hotel market segments. By accomplishing the purposes of this study, this study provides a further understanding of customer behavior in the ever-changing hotel market. 
To achieve the goals of this study, the current study first compares the room rates of two select-service brands (Holiday Inn Express and Hampton Inn) to their fullservice counterparts in the same lodging company (Holiday Inn and Doubletree) by comparing 40 sets of hotels in 20 sets of cities in the United States. Then, online reviews for these hotels were coded and examined using multiple regression to evaluate if the same variables affect star-ratings for select-service and full-service hotels. For marketers, the results reveal what attributes influence guest star-ratings by segment and helps with differentiation. For researchers, this paper extends segmentation theory by researching what happens to room rates and guests' brand perceptions when market segments begin to merge.

The following is the paper's structure. First, there is a review of the relevant literature and hypothesis development. Then, the methodology for the paper is discussed in detail. The results are then presented with supporting tables. The authors then commence a discussion of the results. Finally, the conclusion includes practical and theoretical implications as well as limitations and suggestions for future research.

\section{Literature review}

\subsection{Segmentation theory}

In Smith's (1956) seminal work on marketing theory, the differences between product differentiation and market segmentation were examined. This concept recognizes that consumers, while heterogeneous in character, can be broken into smaller homogenous groups with different products for each segment. It is product differentiation, creating different products to increase market share, and market segmentation is defined as marketing products to different audiences to increase market share (Smith 1956).

In practice, the lodging industry has segmented its markets by creating different products to meet different segments. The full-service hotel, the original accommodations in the lodging industry, have evolved into a product that largely targets groups and conventions (Su and Reynolds 2019). The select-service hotel was designed to meet the needs of the business guests (Grigg 2019). Meanwhile, economy hotels target price sensitive guests (Roper and Carmouche 1989). Prior research has used segmentation theory for segmenting a market, target marketing, and market positioning (Bowen 1998). Research into pricing using segmentation theory, however, has examined customer segments rather than hotel segments (Guo et al. 2013).

This study uses segmentation theory to evaluate the current customer perception of select-service hotels. While hotel marketers initially targeted business travelers for this segment, these hotels have evolved into a product that attracts business and leisure travelers alike (Medina 2017). The current study extends segmentation theory by applying it not to customer segments but to hotel segments by determining if full-service and select-service hotels have different prices, user generated ratings, and factors that determine those star-ratings. The current study draws on the idea that, despite their best efforts, competing brands rarely have truly differentiated products or consumers (Uncles et al. 2012). Prior research suggests that 
segmentation more often tells companies who will not purchase their brand rather than who will (Hammond et al. 1996). In lodging, practitioners have often defined different hotel segments by price (Yapp 2015). This research examined room rates and pricing practices in select-service and full-service hotels to determine if true segmentation exists in these two products.

\subsection{Room rates and pricing}

Hotel room rates have historically been based on competition, profit goals, supply and demand, and price sensitivity of guests (Kim et al. 2004). Revenue management literature often involves looking at theoretical models for optimal room prices that factor in all of the variables needed for determining room rates (Pan 2007) or incorporated risk measurements to prevent loss of revenue by creating models to best optimize pricing (Levin et al. 2008). Market segment has been considered a fundamental part of pricing.

Different pricing levels are commonly considered an indicator the brand's segment. Rates are typically based upon demand and price sensitivity or lack thereof. Customers look at price as an indicator of value when making selections, and their sensitivity to price is dictated by the market for a particular property as well as their range of acceptable prices for that market (Lewis and Shoemaker 1997). According to Piercy et al. (2010), "the way prices are set not only influences demand, but price also shapes how buyers use the product or service and can have a lasting impact on customer relationships." Conversely, when consumers are faced with numerous options when booking online, the relative quality of the hotels is equalized and price sensitivity increases (Diehl et al. 2003). The more choices a person has when booking, the more likely price will become a deciding factor (Arnold et al. 1989). This implies that for hotels, market segment becomes less of a factor when potential guests are looking at a long list of hotels on a third-party site. The current study questions the conventional wisdom of segmentation theory, with the contention that the segmentation of select-service and full-service hotels has become blurred as the select-service segment has evolved.

Revenue managers can take the perspective that revenue per available room (RevPAR) is an accurate predictor of market value for a property and an indicator of brand success (Love et al. 2012), or can entertain the idea that the brand is an indicator of RevPAR potential, (O'Neill and Xiao 2006). Either way, brand and RevPAR have a relationship. Brand loyalty and willingness-to-pay have a complex relationship; guests close to changing their loyalty levels tend to have a greater willingnessto-pay (Mathies and Gudergan 2012), while business travelers with high levels of attitudinal loyalty tend to be more price sensitive than those with lower levels of loyalty (Noone and McGuire 2016). However, for hotel segments, it takes a deeper discount for guests to switch between full-service hotel brands than to switch between select-service hotel brands (Tanford et al. 2012). Therefore, a select service hotel that can consistently command a higher price may have more brand loyal guests.

Hotels' adoption of revenue management means that room rates are fluid (Kimes 1989). The way hotels are priced, however, varies by hotel as there is no universally 
accepted pricing model for "all hotels, at all times and in all places" (Steed and Gu 2005). Previous studies indicate that discounting does not positively contribute to RevPAR. Enz et al. (2009) found that hotels that priced their room 5-10\% higher than the competition saw an increase in RevPAR while those who discounted had higher occupancy but with lower RevPAR. They also noted that the select-service hotels with food and beverage benefited less from discounting than other properties. Therefore, when a property is priced higher than its competitors, it may be a strategy to increase ADR, or it may be because it has higher demand.

\subsection{Select-service hotels}

Select-service hotels have been the most rapidly expanding segment of the hotel market (Mandelbaum 2017). In 2004, select-service hotels began to expand from suburban markets to urban markets (McMullen-Coyne 2004), and in continued to gain popularity with guests in the ensuing years. Select-service hotels have increased in popularity in city centers, with guests opting to use apps like UberEats to enjoy authentic, local food rather than full-service hotels. They are also more cost effective for owners. At the 2019, 70\% of hotels in the U.S. pipeline were select-service hotels. In 2018-2019, the average cost of a full-service hotel was $\$ 390,000$ per room while the average cost of a select-service hotel was $\$ 290,000$ per room (Caufield 2020). Select-service hotels also costs less to run because of the reduced need for staff. During the COVID-19 pandemic, select-service hotels were more resilient due to demand from first responders (JLL 2020), making them a more attractive shortterm investment. Select-service hotels can be adapted internationally due to their simple technology and adaptive service concept (Higgins 2006).

While service remains important regardless of segments (Kim et al. 2016), price has traditionally been the clear-cut difference (Zhang et al. 2011). Research into pricing between hotel classes found that there were significant differences between classes at determined by STR, namely economy, midscale, upper-midscale, upscale, upper-upscale, and luxury (Kim et al. 2020). However, hotel class and segment are not the same thing. STR states that ADR is a determinant of classification and fullservice and select-service hotels are often in the same class (STR 2018). For example, Holiday Inn and brand extensions Holiday Inn Express are both classified as upper mid-scale as are Doubletree and Hampton Inn.

The pricing determinants of economy, mid-scale, and luxury hotels have been found to significantly vary (Zhang et al. 2011), but that study did not distinguish between select-service and full-service midscale hotels. Brand positioning has not always been clear, and major companies often price their select-service hotels primarily based on demand rather than brand positioning (Hilton Revenue Management Personal Communication 2014), thus negating the idea that these hotels were built to attract price sensitive consumers. Research into hotel pricing has found that pricing is related to both demand and online ratings, regardless of segment (Wang et al. 2019). Additionally, guests are less likely to book hotels with high star-ratings if the price is discounted (Jang and Moutinho 2019), which indicates that user-generated star-ratings has more influence on room rate than segment. This, coupled with 
the desirability of select-service hotels with investors (Caufield 2020), indicates that pricing may not be a differentiating factor between segments. With this potential for increased revenues, this research proposes that:

Hypothesis 1 The room rate of the select-service hotel is equal to or higher than its full-service counterpart.

As the construction of hotels continues to accelerate in the U.S. in 2017, full-service hotels have enjoyed a resurgence due to strong group demand (Manley 2017). However, financing for full-service hotels is still hard to find and these new projects are primarily built with public funds. When looking at resale value, in June 2013 a full-service Sheraton in Pittsburgh sold for $\$ 175,000$ per key while a Courtyard in the same market sold for $\$ 226,000$ per key (Schooley 2013). In 2016, many in the industry were predicting the demise of full-service hotels, claiming that they had become obsolete. As evidence, many have cited the preference major hotel chains have shown for developing new select-service brands rather than new full-service brands, like Tru by Hilton, and Hyatt's focus on Hyatt Place and Hyatt House (Ting 2016). These select-service hotels are preferred not only because of the cost to build them but because of the revenue they generate, and high occupancy for select-service hotels demonstrates that consumers value these properties as well. Furthermore, while consumers attribute distinct brand personalities to select-service hotels, their impressions of full-service hotels are much less distinct (Su and Reynolds 2019).

Research into what impacts star-ratings for online reviews and guest satisfaction in hotels strongly indicate that the same antecedents of satisfaction would hold true regardless of segment. A study into what impacts hotel star-ratings on TripAdvisor found that both full-service and select-service hotels can receive good and bad reviews, with value, location, noise, room condition, cleanliness, and service impacting the star-ratings in user-generated content (Rhee and Yang 2015). A study into what impacts guest satisfaction in budget hotels found that price-value and satisfaction with the hotel room were predictors of guest satisfaction (Rahimi and Kozak 2017). This corresponds with studies related to guest satisfaction in full-service hotels (e.g. Lai 2019). Therefore:

Hypothesis 2 Select-service hotels and full-service hotels do not have significantly different star-ratings from user-generated online reviews.

Branding is a key concept in hotel marketing. The purpose of branding is to create a definitive image in the mind of guest that promises certain expectations for the guest (Xia et al. 2020). The history of brand extensions in other industries has indicated that brand extensions have the potential to eclipse the parent brand. When Miller Lite was introduced, it cannibalized the market for Miller High Life. Heinz Ketchup was so successful that it took time and resources away from Heinz's position in the pickle and relish market (Sharp 1993). For both examples, the perception of quality of the original product did not change; for Miller Lite, the product filled an unmet need in the market at the time. While additional research has found that a 
brand extension can dilute the brand image of the parent brand (Martinez and De Chernatony 2004), increasing the difference between the brands can reduce brand erosion for the parent brand and maintain similar consumer perceptions of both brands (Kim et al. 2004).

Within hospitality, brand extensions are common. Research into consumers attitudes have found that positive attitudes towards the parent brand translate to positive attitudes towards the brand extension for a hotel if that brand extension is a stepdown, such as a limited-service extension from a full-service brand, then a step-up (Hultman et al. 2021). Positive brand attitudes towards limited-service brands do not impact the attitudes towards full-service extensions. As hotel brands continue to expand, consumers translate their impression of both the parent brand and all previous brand extensions to the any new brand extensions, thus indicating the importance of managing the brand experience for each brand extension (Mahasuweerachai and $\mathrm{Qu}$ 2015).

Researchers have extensively examined the impact of brand on hotel guests. A study regarding the impact of global expansion on hotel brands found that brand knowledge significantly affects guests' behavioral intentions (Huang and Cai 2015). An examination of the role of discounts and gifts on brand found that discounts are less likely to impact brand image than free gifts (Crespo-Almendros and Del Barrio-Garcia 2016). Brand image has also been found to significantly affect the relationship between online reviews and booking intentions (Casado-Díaz et al. 2017). Therefore, it follows that brand would affect star-ratings.

Traditionally, brand is not considered a part of the equation in determining the room rate for a hotel. This study has endeavored to prove that when a brand has a strong positive presence in the mind of the guest, the guest is willing to pay a premium for that brand regardless of market segment. As Chris Elder stated in his work, "the line between full-service and the select-service hotels has become increasingly blurred," (Elder 2010) and with this blurring, it is logical that guests would have a similar expectation for hotels in each segment. Furthermore, when hotel guests compare full-service and select-service properties, they often find that the rooms and service experience are almost identical (Mogelonsky 2015). Therefore,

Hypothesis 3 Due to the blurring of segments, determinants of star-ratings are not significantly different for the select-service and full-service hotels.

\section{Methodology}

\subsection{Data collection}

To empirically investigate the difference in room rates between select-service and full-service hotels, this study first investigated two sets of hotels from two major hotel brands, DoubleTree (DT) and Hampton Inn (HP), and Holiday Inn (HI) and Holiday Inn Express (HIE). HIE and HP were chosen because they are considered two of the most successful select-service brands (Timmermann 2019). Both brands adhere to the traditional standard of a select service hotel in terms of food 
and beverage options being limited to free breakfast; while Courtyard by Marriott is also a highly successful select-service brand, the Bistro's extended offerings along with the Bistro-to-Go room service product (Timmermann 2019) make it unique and therefore was excluded from this study. HI and HIE were chosen to examine the relationship between a brand and brand extension. HP and DT were chosen to examine the relationship between two acquired brands in the same brand family.

Room rates were shopped for 20 sets of HI and HIE hotels, from September 1, 2014, through February 28, 2015. To confirm the relationship and extend generalizability, this paper collected room rates for another full-service and select-service brand pair: the DT and HP from September 1, 2016, through February 28, 2017. To choose sample, following criteria are used. First, all the pairs of hotels should be located within five miles of each other in their respective city. Second, the hotels should have been opened for the 6 months of rate data collection without closure. Six month was used to control for factors such as corporate promotions, seasonality, and other anomalies that might affect the rate. Third, to prevent regional bias, the sample cities should be diversified. New York, Chicago, and Los Angeles, as well as resort destinations, were purposefully excluded from this study due to the uniqueness of those destinations that would limit generalizability to the rest of the country.

The same cities were used for both sets of hotels when available; however not all four brands were always present in the same cities that qualifies the rule. See Table 1 for the complete list. This study examines the best available rate (BAR) rather than the actualized average daily rate (ADR) because of the limited availability of brand

Table 1 Cities sampled

\begin{tabular}{ll}
\hline Holiday inn and holiday inn express & DoubleTree and hampton inn \\
\hline Atlanta, GA & Atlanta, GA \\
Austin, TX & Austin, TX \\
Bloomington/Normal, IL & Bloomington/Normal, IL \\
Colorado Springs, CO & Colorado Springs, CO \\
Des Moines, IA & Des Moines, IA \\
Helena, MT & Missoula, MT \\
Houston, TX & Houston, TX \\
Manchester, NH & Bedford, MA \\
Nashville, TN & Nashville, TN \\
Orlando, FL & Orlando, FL \\
Danbury, CT & Norwalk, CT \\
Phoenix, AZ & Phoenix, AZ \\
Portland, OR & Portland, OR \\
Raleigh, NC & Raleigh, NC \\
San Diego, CA & San Diego, CA \\
San Francisco, CA & San Francisco, CA \\
Seattle, WA & Seattle, WA \\
St. Louis, MO & St. Louis, MO \\
Richmond, VA & Virginia Beach, VA \\
Dover, DE & Wilmington, DE \\
\hline & \\
\hline
\end{tabular}


specific data and because BAR is exempt from the impact of reward and discounted nights.

During the course of this rate survey, the HI in Urbana, Illinois dropped its brand flag and became the Urbana Plaza Hotel and Conference Center. This necessitated a change from looking at rates for a set of hotels in Urbana to the HI and HIE in Bloomington-Normal, Illinois. Bloomington-Normal is very similar to UrbanaChampaign; the largest demand driver in both areas are large state universities, both are located in Central Illinois, and the cities are 53 miles apart. Also, the HI Orlando maintained its flag during the course of the study but has been rebranded since the time of the data collection to the Heart of I-Drive Hotel. The HI Nashville is now the Nashville Airport Hotel. The HIE La Mesa has become the Best Western Plus La Mesa.

To analyze the data, four four-way multilevel models were run in SPSS 24. The analyses determined the effects of service level (select-service and full-service), brand, city, and date renovated. Service-level was dummy coded as were brand and city. For properties that had not undergone a major renovation before the study period, the year the property was built was used as the date renovated. The year renovated was coded as a number from the dates of the data collection, 2016, minus the year it was renovated. Therefore, a property renovated in 2016 would be coded as 0 while a property that was renovated in 2012 would have a coding of 4 ; the lower number represents a more recently renovated property. Four model were run to determine the fixed effects of each of the variables on the average room rate. Appendix A contains the syntax used to run each of the models.

To examine Hypotheses 2 and 3, to determine if there was a significant difference between star-ratings for full-service and select-service hotel and to determine which attributes effect star-ratings in those segments, customer reviews from TripAdvisor, Expedia, and the brand website were collected. In order to reduce potential problem resulted from specific review sites and control the variability between websites, reviews were collected from three different online review platforms. Expedia and the brand website both post reviews from verified guest stays; however, these companies have a vested interest in the content of their on-line reviews. TripAdvisor is considered a neutral site because it has only recently become a booking site; however, the reviewers are not verified travelers. For DT and HI, this study utilized TripAdvisor and Expedia for all of the reviews because the reviews on Hilton.com come directly from TripAdvisor; therefore, they are not unique and could be duplicates of the reviews on TripAdvisor.

For HI and HIE, this study used first available 15 reviews and star-ratings from each of the three websites, TripAdvisor, Expedia, and IHG.com. For DT and HP, 23 were taken from TripAdvisor and 22 from Expedia, to make the total number of reviews equal to 45 . Therefore, a total of eighteen hundred reviews were examined for each hotel brand $((15 \times 3 \times 20 \times 2)+((23+22) \times 20)=3,600)$. For Hypothesis 2 , the researchers applied multilevel modeling using SPSS.

Hypothesis 3 was to compare the variables that affect the star-ratings of selectservice and full-service hotels. To answer the question, ordinal logistic regression analysis was conducted. In this study's case, star-ratings was the dependent variable. Star-ratings range from 1 through 5 , with 1 being the lowest rate and 5 the highest. 
Based on Levy et al. (2012), which found variables to have a significant impact on star-ratings for online reviews, 12 factors affecting guests' satisfaction are identified: location, parking, bathroom, noise, room size, room condition, restaurant, air conditioning, safety, cleanliness, housekeeping staff and front desk staff. Levy et al. (2012) included bugs and other creatures; however, this study excluded the variable since this was not mentioned in any of the reviews pulled for the analysis. This paper added Brand as a factor to affect star-ratings. To make sure the reliability and validity of the review analysis, raters were provided a full description of the proposed 12 factors with examples. When the raters had questions during their evaluation process, a further explanation was provided. Once the raters fully comprehended how to assess the factors, the raters were asked to assign a specific value indicating how the review described the factor. Specifically, the reviews were coded 1 for a positive mention, -1 for a negative mention, and 0 if it was not mentioned. For example, a positive value of one was assigned if a reviewer mentioned, "It was right by downtown/highway", whereas a negative one was assigned for a review saying, "The hotel was so far away from the attractions." Once the initial evaluation of reviews was completed, a second round assessment was conducted to ascertain the accuracy of review analysis. The assessment of the raters was compared to ensure a sufficient inter-rater reliability. While there was not much discrepancy between the two raters in their evaluation of 3,600 reviews, any discrepancies were resolved through a series of discussions so that the raters had a complete agreement.

As a result, the model has a total 26 independent variables. The model was:

$$
\begin{aligned}
\text { STARRATING }_{i}= & a_{0} \\
& +a_{1} \text { PBRAND }_{i}+a_{2} \text { NBRAND }_{i}+a_{3} \text { PLOCATION }_{i}+a_{4} \text { NLOCATION }_{i} \\
& +a_{5} \text { PPARKING }_{i}+a_{6} \text { NPARKING }_{i}+a_{7} \text { PBATHROOM }_{i}+a_{8} \text { NBATHROOM }_{i} \\
& +a_{9} \text { PNOISE }_{i}+a_{10} \text { NNOISE }_{i}+a_{11} \text { PROOMSIZE }_{i}+a_{12} \text { NROOMSIZE }_{i} \\
& +a_{13} \text { PROOMCOND }_{i}+a_{14} \text { NROOMCOND }_{i}+a_{15} \text { PRESTAURANT }_{i} \\
& +a_{16} \text { NRESTAURANT }_{i}+a_{17} \text { PAIRCON }_{i}+a_{18} \text { NAIRCON }_{i}+a_{19} \text { PSAFETY }_{i} \\
& +a_{20} \text { NSAFETY }_{i}+a_{21} \text { PCLEAN }_{i}+a_{22} \text { NCLEAN }_{i t}+a_{23} \text { PHOUSEKP }_{i}+a_{24} \text { NHOUSEKP }_{i} \\
& +a_{25} \text { PFRONTDESK }_{i}+a_{26} \text { NFRONTDESK }_{i}+\varepsilon_{i}
\end{aligned}
$$

where STARRATING is the average of star-ratings for each property from all websites sampled; $\mathrm{P}$ is the positive independent variable for each factor that is measured; $\mathrm{N}$ is the negative independent variable for each factor; $\varepsilon$ represents an error term; subscript of $I$ represents individual hotel firm.

For the analysis, each independent variable is a dummy variable with an assigned value of 1 if a comment indicates such item and 0 otherwise. For example, if a comment indicates positive room condition, negative restaurant, and positive front desk, PROOMCOND, NRESTAURANT, and PFRONTDESK are indicated 1 and 0 for all other variables. Neutral comment and no comment were considered the same with the assigned value of 0 because (1) there are few neutral comments found, and (2) the difference between impact of neutral comment and no comment is considered insignificant. 


\section{Results}

\subsection{Room rates comparison}

To examine the rates between select-service hotels and full-service hotels, this study conducted a series of four-way multi-level model to examine the fixed effects and random effects of four variables on room rate: service level, brand, city, and data renovated. Table 2 illustrates these results. The unconditional model yielded a statistically significant city variance of 227.87 along with a statistically significant residual variance of 739.11. The ICC (Intercept/Sum of Intercept + Residual) was calculated to be 0.236 , indicating that $24 \%$ of the total variance of average room rate is associated with the city. The assumption that mean BAR is independent of city effects is therefore violated. For the conditional model, the ICC was calculated to be $1(450.22 / 450.22+0)$, which is greatly improved from the unconditional model. The log likelihood of the conditional model (219.475) also decreased from the unconditional model (785.597), indicating that it is a better fit. There was a statistically significant difference between the average room for select-service and full-service hotels $(\mathrm{B}=138.176, \mathrm{SE}=5.145)$ as well as for IHG and Hilton branded hotels $(\mathrm{B}=138.225, \mathrm{SE}=5.146)$. Table 2 outlines these results.

\subsection{Customer satisfaction comparison}

To compare the customer perceptions of the select-service and full-service hotels, 45 star-ratings were examined for each of the 80 hotels from a total of 20 cites, for a total of 3600 reviews. To examine the difference in the ratings, paired $t$-tests were run between the hotel sets in each city (i.e. HIE vs. HI in Atlanta, HP vs. DT in Atlanta etc.). Table 3 reports star-ratings for HI and HIE, and for DT and HP, respectively, for each individual city and all the sampled cities.

Table 2 Results of multi-level modeling

\begin{tabular}{lll}
\hline & \multicolumn{2}{l}{ Model summaries } \\
\cline { 2 - 3 } & Unconditional model & Conditional model \\
\hline Residual variance & 739.112 & 0.000 \\
Intercept variance & $227.873^{* * *}$ & $450.216^{\dagger}$ \\
Intra-class correlation & 0.236 & 1.000 \\
Log likelihood & 785.597 & 219.475 \\
\hline & Estimates of fixed effects & \\
\cline { 2 - 3 } & Beta & Standard errors \\
\hline Intercept & $-151.945^{* * *}$ & 10.829 \\
Service level (select-service) & $138.176^{* * *}$ & 5.145 \\
Firm (intercontinental hotel group) & $138.225^{* * *}$ & 5.460 \\
\hline
\end{tabular}

$\dagger, *, * *, * * *$ Denote significant at the $0.10,0.05,0.01$, and 0.001 levels, respectively 
Table 3 Customer satisfaction comparisons-main model

a. HI and HIE

\begin{tabular}{|c|c|c|c|c|c|c|}
\hline City & Number of obs & Mean HI & Mean HIE & Mean HI - HIE & $\mathrm{HIE}>\mathrm{HI}$ & $\mathrm{HIE}<\mathrm{HI}$ \\
\hline Atlanta & 45 & 3.69 & 3.64 & -0.05 & & $\dagger$ \\
\hline Austin & 45 & 4.69 & 4.02 & -0.67 & & $\dagger$ \\
\hline Bloomington-Normal & 45 & 4.11 & 4.44 & 0.33 & $* * *$ & \\
\hline Colorado Springs & 45 & 4.13 & 4.22 & 0.09 & & \\
\hline Danbury & 45 & 4.29 & 4.27 & -0.02 & & $* * *$ \\
\hline Des Moines & 45 & 3.60 & 4.31 & 0.71 & $* * *$ & \\
\hline Dover & 45 & 3.73 & 4.58 & 0.85 & & \\
\hline Helena & 45 & 4.27 & 4.40 & 0.13 & $* * *$ & \\
\hline Houston & 45 & 3.40 & 4.04 & 0.64 & $* * *$ & \\
\hline Manchester & 45 & 3.96 & 3.87 & -0.09 & & \\
\hline Nashville & 45 & 4.24 & 4.29 & 0.05 & $* * *$ & \\
\hline Orlando & 45 & 3.04 & 4.16 & 1.12 & & \\
\hline Phoenix & 45 & 3.82 & 4.09 & 0.27 & & \\
\hline Portland & 45 & 4.27 & 4.31 & 0.04 & & \\
\hline Raleigh & 45 & 3.89 & 4.33 & 0.44 & $* * *$ & \\
\hline Richmond & 45 & 4.42 & 4.40 & -0.02 & & $* * *$ \\
\hline San Diego & 45 & 3.00 & 3.69 & 0.69 & $* *$ & \\
\hline San Francisco & 45 & 3.27 & 4.02 & 0.75 & $* *$ & \\
\hline Seattle & 45 & 4.13 & 4.31 & 0.18 & $* * *$ & \\
\hline St Louis & 45 & 3.87 & 4.49 & 0.62 & $* * *$ & \\
\hline All Hotels & 900 & 3.95 & 4.29 & 0.25 & $* * *$ & \\
\hline
\end{tabular}

b. HP and DT

\begin{tabular}{|c|c|c|c|c|c|c|}
\hline City & Number of obs & Mean DT & Mean HP & Mean HP - DT & $\mathrm{HP}>\mathrm{DT}$ & $\mathrm{HP}<\mathrm{DT}$ \\
\hline Atlanta & 45 & 3.38 & 4.40 & 1.02 & $* *$ & \\
\hline Austin & 45 & 4.20 & 4.58 & 0.38 & $* *$ & \\
\hline Bedford & 45 & 4.16 & 3.93 & -0.23 & & * \\
\hline Bloomington-Normal & 45 & 4.33 & 4.36 & 0.03 & $*$ & \\
\hline Colorado Springs & 45 & 3.72 & 3.82 & 0.10 & & \\
\hline Des Moines & 45 & 4.57 & 3.98 & -0.59 & & $* *$ \\
\hline Houston & 45 & 3.76 & 4.00 & 0.24 & & \\
\hline Missoula & 45 & 3.69 & 4.51 & 0.82 & $* * *$ & \\
\hline Nashville & 45 & 3.42 & 4.09 & 0.67 & $* * *$ & \\
\hline Norwalk & 45 & 4.02 & 4.69 & 0.67 & $* * *$ & \\
\hline Orlando & 45 & 3.84 & 4.42 & 0.58 & $*$ & \\
\hline Phoenix & 45 & 4.00 & 4.33 & 0.33 & $*$ & \\
\hline Portland & 45 & 3.84 & 4.24 & 0.40 & $* *$ & \\
\hline Raleigh & 45 & 3.84 & 4.53 & 0.69 & $* *$ & \\
\hline San Diego & 45 & 3.87 & 4.57 & 0.70 & $* *$ & \\
\hline San Francisco & 45 & 4.60 & 4.31 & -0.29 & $* *$ & \\
\hline Seattle & 45 & 4.18 & 4.16 & -0.02 & & \\
\hline
\end{tabular}


Table 3 (continued)

b. HP and DT

\begin{tabular}{|c|c|c|c|c|c|c|}
\hline City & Number of obs & Mean DT & Mean HP & Mean HP - DT & $\mathrm{HP}>\mathrm{DT}$ & $\mathrm{HP}<\mathrm{DT}$ \\
\hline St. Louis & 45 & 4.18 & 4.16 & -0.02 & & \\
\hline Virginia Beach & 45 & 3.71 & 4.38 & 0.67 & $* *$ & \\
\hline Wilmington & 45 & 3.91 & 4.64 & 0.73 & $* * *$ & \\
\hline Total & 900 & 3.96 & 4.31 & 0.34 & $* * *$ & \\
\hline
\end{tabular}

$\dagger, *, * *, * * *$ Denote significant at the $0.10,0.05,0.01$, and 0.001 levels, respectively

HI, HIE, DT, and HP refer to Holiday Inn, Holiday Inn Express, DoubleTree, and Hampton Inn, respectively

Overall, the select-service brands for both brand pairs had significantly higher star-ratings. The average star-ratings for HIE was 4.29 vs. 3.95 for the $\mathrm{HI}$ and it was statistically significantly higher in ten cities. The average star-ratings for HP was 4.31 vs. 3.96 for the DT and it was statistically significantly higher in fourteen cities. These results do not support Hypothesis 2 that there will be no significant difference between the star-ratings for select-service and full-service hotels. These findings might be attributed to consumers have a lower expectation for select-service hotels, resulted from their preconception that the level of services would be related to their service quality. This, despite the similar or higher price of select-service hotels, consumers' expectation for select-service might be low, leading to higher customer satisfaction.

\subsection{Factors that affect customer satisfaction}

To examine which variables effect customer satisfaction, measured by star-ratings, each individual review was coded for the 13 factors: location, parking, bathroom, noise, room size, room condition and furniture, restaurant, air conditioning, safety, cleanliness, housekeeping staff, front desk staff, and brand. This paper adds a new variable "Brand." Brand was a mention of the brand name of the property (i.e. Hampton Inn), the brand name of the company (i.e. Hilton) or the brand name of the loyalty program (i.e. Hilton Honors) but not a mention of the property itself (i.e. Hampton Inn Baltimore Inner Harbor). Two raters reviewed each of 3,600 online reviews and coded; each factor for each review was rated 1 for a positive comment, - 1 for a negative comment, and 0 for neutral comment.

The results of the regression partially supported Hypothesis 3. Table 4 reports the main findings. Certain factors were significant across all four brands. Of the 26 independent variables (positive or negative for each 13 variables), 10 variables were statistically significant at the 0.05 or lower across all four brands and five were not significant for any of the brands (positive mentions of location, positive mentions of noise, positive mentions of room size, positive mentions of air conditioning/heating, and positive mentions of safety). Negative mentions of parking, bathroom, noise, room condition, restaurant, air conditioning/heating, cleanliness, and front desk service were statistically significant across all four brands by 
Table 4 Factors that affect customer satisfaction

\begin{tabular}{|c|c|c|c|c|}
\hline Variables & Holiday inn & Holiday inn express & DoubleTree & Hampton inn \\
\hline PBrand & -0.514 & -0.173 & -0.139 & $0.178 * *$ \\
\hline NBrand & $-1.000 * *$ & 0.367 & $-0.480 * *$ & $-0.480 *$ \\
\hline plocation & 0.350 & 0.851 & 0.116 & 0.036 \\
\hline nlocation & $-1.002 * *$ & -0.359 & -0.093 & $-0.343^{*}$ \\
\hline pparking & $0.594 *$ & -0.420 & 0.066 & -0.023 \\
\hline nparking & $-0.863^{*}$ & $-0.927 *$ & $-0.316^{* *}$ & $-0.358 * *$ \\
\hline pbathroom & -0.196 & $1.017 *$ & 0.016 & 0.088 \\
\hline nbathroom & $-1.111^{* * *}$ & $-1.328 * * *$ & $0.393 * * *$ & $-0.423^{* * *}$ \\
\hline Pnoise & 0.267 & 0.153 & 0.158 & 0.046 \\
\hline Nnoise & $-1.176^{* * * *}$ & -1.285 & $-0.603 * * *$ & $-0.444 * * *$ \\
\hline Prmsize & 0.334 & 0.129 & 0.041 & 0.018 \\
\hline Nrmsize & $-0.736^{*}$ & $3.870 * * *$ & $-0.396^{\dagger}$ & $-0.567 * * *$ \\
\hline prmcondition & $0.667 * * *$ & $4.290 * * *$ & 0.098 & $0.109^{*}$ \\
\hline nrmcondition & $-1.541^{* * *}$ & $4.160 * * *$ & $-0.841^{* * *}$ & $-0.688^{* * *}$ \\
\hline prestaurant & $0.574 * * *$ & 0.606 & $0.140 *$ & $0.087^{\dagger}$ \\
\hline nrestaurant & $-0.648 * * *$ & -0.501 & $-0.427 * * *$ & $0.356^{* * *}$ \\
\hline Paircon & 0.494 & 1.664 & -0.101 & -0.135 \\
\hline Naircon & $-1.265^{* * *}$ & $-1.191 * *$ & $-0.594 * * *$ & $0.361 * *$ \\
\hline Psafety & 0.644 & 1.179 & -0.254 & 0.186 \\
\hline Nsafety & $-2.729^{\dagger}$ & -0.634 & $-0.521 * *$ & -0.582 \\
\hline Pcleanliness & 0.205 & 0.142 & $0.150 *$ & 0.050 \\
\hline Ncleanliness & $-1.333^{* * *}$ & $-1.965^{* * * *}$ & $0.573 * * *$ & $-0.955 * * *$ \\
\hline phousekeeping & 0.030 & 0.278 & 0.190 & $0.285^{\dagger}$ \\
\hline nhouskeeping & $-1.416^{* *}$ & -0.672 & -0.224 & 0.145 \\
\hline Pfrontdesk & $0.780 * * *$ & $0.753 * * *$ & $0.181^{* *}$ & $0.254 * * *$ \\
\hline Nfrontdesk & $2.322 * * *$ & $-2.222 * * *$ & $-0.951 * * *$ & $-1.007 * * *$ \\
\hline $\mathrm{R}^{2}$ & $25.0 \%$ & $23.3 \%$ & $55.9 \%$ & $40.0 \%$ \\
\hline
\end{tabular}

$\dagger, *, * *, * * *$ Denote significant at the $0.10,0.05,0.01$, and 0.001 levels, respectively

negatively influencing star-ratings. Positive mentions of the restaurant and front desk were statistically significant across all four brands by positively influencing star-ratings, noting that for the HIE and HP, the restaurant was the complimentary breakfast offered by those brands. Positive mentions of room condition were statistically significant for HI, HIE, but not for DT. Negative mentions of the restaurant were statistically significant for HI, DT, and HP but not for HIE. Negative mentions of location were significant for brands HI and HP and negative mentions of safety were significant for the full-service brands, HI and DT.

In summary, Hypothesis 1 was fully supported, Hypothesis 2 was not supported, and Hypothesis 3 was partially supported. Hypothesis 3, which examined the antecedents of satisfaction for select-service and full-service hotels, found 
that brand was the only antecedent that had a different impact by segment. Our results demonstrate that negative brand mentions were significant for the fullservice brands and HP while positive brand mention was only significant for HP. This demonstrates that brand image affects star-ratings for online reviews. These results are discussed in detail in the next section.

\section{Discussion}

Drawing on segmentation theory, this study researched the concept that two market segments within the lodging industry-select-service and full service-have begun to converge in terms of pricing and customer perception. Hypothesis 1 predicted that the room rate for select-service hotels would be equal to or higher than full-service properties. The results of the multi-level modelling indicated that segment was not significant while brand was when accounting for effects by city and length of time from the most recent remodel. Hypotheses 2 and 3 examined the impact of segmentation on user-generated star-ratings on TripAdvisor, Expedia, and the brand homepage. While Hypothesis 2 stated that select-service would not have a significantly different star-ratings than their full-service counterpart, this study found that both the HP and HIE had higher user-generated star-ratings than DT and HI. Hypothesis 3 stated that because of the blurring of the hotel segments, the antecedents of usergenerated star-ratings on online review websites would not be significantly different. This was mostly supported with the notable exception of brand.

The examination of a brand name and its influence on star-ratings was unique to this study. This study drew from the work of Hammond et al. (1996), which examined the relationship between brand and segmentation. They found that customers of the same product type do not differ by brand, therefore the mention of the brand would be expected to be similar for HI and DT and HIE and HP. In this study, the reviewers coded the review with 1 if there was a mention of the brand, parent brand, or rewards program separate from the hotel (i.e. not a mention for the DT Austin). For the HIE, brand was not significant either in a positive or negative mention. For HI and DT, the full-service brands, negative mentions of brand were significant in a negative direction. This means that a negative perception of brand had a negative influence on the overall star-ratings. For HP, brand was statistically significant for both positive and negative mentions. Positive perceptions of the brand had a significant effect on the star-ratings while negative perceptions of the brand had a negative influence on the star-ratings. However, it is notable that the negative brand mentions for HP were mentions of the loyalty program or the parent brand (Hilton Honors and Hilton Hotels) and not negative mentions of HP's brand. These results echo prior research into online reviews that found that brand image had a moderating impact on the impact of star-ratings on booking intentions (El-Said 2020).

The current study specifically examined a brand pair that had a brand extension (HI and HIE) and a brand pair that were not a brand extension (HP and DT). The results of this study indicate that for the brand and brand extension pair, consumers compared the brands to each other. Indeed, many of the negative reviews for the HI compared it unfavorably to the HIE. These results support previous research related 
to brand extensions in that the brand extension can change consumer expectations for the parent brand (Martinez and De Chernatony 2004). However, the discussion of brand between DT and HP do not compare either brand to each other or to other specific brands but rather the specific brand experience for that brand. Therefore, these results indicate that a direct brand extension has an impact on consumer perception while brands in the same family that are not directly related do not directly affect each other.

Traditionally, brand is not considered a part of the equation in determining the room rate. This study has endeavored to prove that when a hotel has a strong brand image, the guest is willing to pay a premium for that brand regardless of market segment. As Chris Elder stated in his work on hotel classes, "the line between fullservice and the select-service hotels has become increasingly blurred," and with this blurring, it is logical that the line between price has become blurred as well (Elder 2010). The review of star-ratings shows that the HIE has a significantly higher starratings than the $\mathrm{HI}$, and six of the hotels with the significantly higher rating also had significantly higher rates. HP had significantly higher star-ratings than the DT, and eight of the hotels with significantly higher star-ratings also had significantly higher room rates.

The significant impact of brand on room rates and star-ratings is expected to remain significant, if not more, during and after the COVID-19 pandemic. During a crisis, restoring customer confidence is crucial to rebound the business and hotel brands are found proactive for recovery activities (Hao et al. 2020). Initiation of free cancellation, re-booking assistance, extension of loyalty program membership are a few examples that are offered by hotel brands on top of employing strict hygiene and sanitary protocols. Not only were they effective in developing such strategies, hotel brands were effective in communication. Hotel brands' reactions will strengthen customers' emotional attachment to brands, which will be crucial for recovery of businesses during and after the pandemic (Hang et al. 2020).

Even though literature supports the stance that a fundamental difference between a full-service and select-service hotel is room rate (Tanford et al. 2012; Yapp 2015), our findings demonstrate that this is not necessarily the case. For this sample, service level did not have a significant impact on the average room for the observation period when controlling for brand, city, and date renovated. The interception of brand and city effects had the most significant impact on average room rate. This supports previous research, which found that brand image affected consumers booking intentions for hotels (Casado-Díaz et al. 2017).

\section{Conclusion}

The current study sought to understand customer perceptions of full-service and select-service brands in the same brand family. Since select-service were first introduced in the 1980's, there has been a proliferation of select-service brand extensions with increased amenities and unique concepts to capture different niche markets. Brand, a traditional indicator of quality for many consumers (Elder 2010), was studied as a unique variable. 
The current paper found that brand rather than segment affected room rate while more customers were satisfied with select-service hotels rather than full-service hotels. Retail and marketing researchers have previously documented risks associated with brand extensions that eclipse their parent brand (Sharp 1993), while may be the case for Holiday Inn Express. However, this would not account for the preference for Hampton Inn; instead, it seems to be the brand itself.

In this study, the select-service brands had a statistically higher room rate for 19 of the 40 sets of hotels. For the hotels in this study, room rate is no longer a differentiating factor between these two market segments. When investigating user generated star-ratings, the select-service brands had higher star-ratings than the fullservice brands. This may echo the industry sentiment that full-service hotels are no longer the dominant segment in the lodging market (Ting 2016). Guests at hotels in both segments were affected by many of the same factors in terms of customer satisfaction, including cleanliness and front desk guest service. This study also found evidence that brand has a significant impact on star-ratings, demonstrating that customers in both segments can form an emotional attachment to the brand. This result supports previous findings in the lodging industry context by indicating that brand image frames the guest stay before they even check-in and provides a reference for everything they experience during their stay (Anselmsson et al. 2014).

This study also examined what matters most in online reviews for select-service and full-service hotels. For select-service hotels, brand, location, parking, bathroom, noise, room size, room condition, air conditioning, cleanliness, and the experience at the front desk all affected overall star-ratings. For full-service hotels, these same antecedents had a significant impact on star-ratings, with safety and housekeeping also having an impact on star-ratings. Findings of this study support previous research into hotel star-ratings (e.g. Kim et al. 2016) while expanding it to an investigation by segment and within the same brand family.

\subsection{Practical implications}

By filling the gap in the research regarding the impact of brand and segment on pricing and star-ratings, the current study can assist lodging companies to make better decisions regarding revenue management and customer service. The findings of the study revealed that segment was not a significant factor differentiating prices while brand had a significant impact. Therefore, hotel revenue managers are highly recommended to consider their brand image when developing their pricing strategies rather than relying on traditional pricing criteria such as level of services. Policies that restrict select-service hotels from pricing their rooms higher than a full-service counterpart in the same market may be leaving money on the table. Particularly, such select-service hotels with favorable brand images might need to set their price higher than typical select-service hotels because customers are willing to pay more to stay with them.

Conversely, full-service properties should not restrict their discounting efforts when there is an operational need. Using discounting efforts is especially critical for full-service hotels with a relatively weak brand image since they cannot use 
their brand as a premium to justify their price level. This becomes especially true when hotels are trying to compete with disruptors like Airbnb and other peer-to-peer accommodations websites as research has indicated that price is often a determining factor when choosing between different types of hotels and peer-to-peer accommodations (Xie and Kwok 2017).

Additionally, as the hotel industry begins to recover from the COVID-19 pandemic, many full-service properties have been forced to close outlets due to local restrictions or as a cost saving measure (Van Stekelenburg et al. 2020). The current research indicates that consumers are more willing to pay for a hotel with a higher brand image, regardless of the amenities offered, and that heavy discounting might not be needed.

\subsection{Theoretical implications}

Theoretically, this paper contributes to segmentation theory by expanding the theory to hotel segments and by examining the role of brand in terms of influencing the perception of the market segment. Despite the proliferation of brand expansions by lodging companies to attract different market segments (Braun 2016), this is the first study to the knowledge of the researchers to examine brand expansions through segmentation theory. Additionally, while researchers found that geographic diversification is more likely to positively and significantly affect the company's revenue than brand diversification (Kang and Lee 2014), the current study indicates that brand expansions may be more profitable than the main brand, which opens up more future studies. This study also suggests that brand may be important than segment, in terms of affecting star-ratings and price, which would expand the concept of segmentation to include branding.

This study has found that, while lodging companies seek to differentiate their properties by the amenities offered and the size of the property, guests mention the same factors when discussing their experiences at both full-service and select-service hotels. First, this implies that it may be time for a realignment of the different services offered in full-service and select-service brands. When Marriott first developed the Courtyard brand, they conducted a choice-based conjoint analysis study to measure the impact of each hotel service on business guests' willingness-to-pay (Wind et al. 1989). The current research indicates that it may be time to conduct a similar study for each of the three major segments: business, leisure, and group. If the major antecedents of satisfaction are consistent across segment, then these factors are no longer the deciding factor and new antecedents need to be explored.

\section{Limitations and future research}

This paper is not without limitations. This study is limited to cities within the United States. Researchers are encouraged to conduct an examination of full-service and select-service hotels in international markets to determine if these findings are applicable in other geographic areas. Additionally, a cross-cultural study examining brand 
image in different cultures would be warranted to help lodging companies make decisions about their brand profiles. Hospitality researchers have found that creating local differences for international brands can increase customers' satisfaction (Jeong et al. 2019); future research into the difference between local innovation in full-service and select-service hotels and their impact on customer satisfaction would also further the work in segmentation theory. A topic of interest could be comparing different brands in the same brand family and same market segment but with different brand images, such as Town Place Suites by Marriott and Springhill Suites by Marriott. Additionally, future studies can also examine the impact of brand on customer experience and the impact of brand on price across different segments.

While this paper expands the use of segmentation theory to hotel brands, it does not fully explain why consumers choose one brand over another. Future research could conduct survey related to consumer impressions of different brands. Finally, this paper examined 2 examples of brand extensions. Future research could expand this study to additional brands and brand expansions and pair it with a survey to better understand both the supply and demand side of pricing and online reviews for brands and brand expansions.

\section{Appendix A}

DATASET NAME DataSet1 WINDOW=FRONT.

MIXED mean BY City WITH ServiceLevel Firm DateBuilt DateRenovated

$/ C R I T E R I A=C I N(95) \quad$ MXITER(100) MXSTEP(10) SCORING(1) SINGULAR(0.000000000001) HCONVERGE(0,ABSOLUTE) LCONVERGE(0, ABSOLUTE) PCONVERGE(0.000001, ABSOLUTE)

/FIXED $=$ ServiceLevel Firm DateBuilt DateRenovated ServiceLevel*Firm ServiceLevel*DateBuilt

ServiceLevel*DateRenovated Firm*DateBuilt Firm*DateRenovated

DateBuilt*DateRenovated

ServiceLevel*Firm*DateBuilt ServiceLevel*Firm*DateRenovated ServiceLevel*D ateBuilt*DateRenovated

Firm*DateBuilt*DateRenovated ServiceLevel*Firm*DateBuilt*DateRenovated । SSTYPE(3)

$/ \mathrm{METHOD}=\mathrm{REML}$

/PRINT=CPS DESCRIPTIVES SOLUTION TESTCOV

/RANDOM=ServiceLevel Firm DateBuilt DateRenovated ServiceLevel*Firm ServiceLevel*DateBuilt

ServiceLevel*DateRenovated Firm*DateBuilt $\quad$ Firm*DateRenovated

DateBuilt*DateRenovated

ServiceLevel*Firm*DateBuilt ServiceLevel*Firm*DateRenovated ServiceLevel*D ateBuilt*DateRenovated

Firm*DateBuilt*DateRenovated ServiceLevel*Firm*DateBuilt*DateRenovated । COVTYPE(VC). 


\section{References}

Anselmsson J, Bondesson NV, Johansson U (2014) Brand image and customer' willingness to pay a price premium for food brands. J Prod Brand Manag 23:90-102

Arnold DR, Hoffman KD, McCormick J (1989) Service pricing: a differentiation premium approach. J Serv Mark 3:25-33

Bowen JT (1998) Market segmentation in hospitality research: no longer a sequential process. Int J Contemp Hosp Manag 10:289-296

Braun R (2016) Hotels-brand expansion or brand explosion? Lexology. https://www.lexology.com/libra ry/detail.aspx?g=6a8a9d81-b6fb-4f92-88e6-4474218564cd. Accessed 5 June 2021

Casado-Díaz AB, Pérez-Naranjo LM, Sellers-Rubio R (2017) Aggregate consumer ratings and booking intention: the role of brand image. Serv Bus 11:543-562

Caufield J (2020) 'Lifestyle' is adding new color to the select-service hotel sector. Building design + construction. https://www.bdcnetwork.com/lifestyle-adding-new-color-select-service-hotel-sector. Accessed 18 April 2021

Collins M, Parsa HG (2006) Pricing strategies to maximize revenues in the lodging industry. Int J Hosp Manag 25:91-107

Crespo-Almendros E, Del Barrio-García S (2016) Do online discounts and free gifts damage brand image of service? The moderating role of promotion-proneness. Serv Bus 10:31-58

Diehl K, Kornish LJ, Lynch JG Jr (2003) Smart agents: when lower search costs for quality information increase price sensitivity. J Consum Res 30:56-71

El-Said OA (2020) Impact of online reviews on hotel booking intention: the moderating role of brand image, star category, and price. Tour Manag Persp 33:100604

Elder C (2010) An overview of hotel asset classes. US Hotel Appraisals. http://www.ushotelappraisals. com/services/select-service-hotels. Accessed 18 April 2021

Enz CA, Canina L, Lomanno M (2009) Competitive pricing decisions in uncertain times. Cornell Hosp Q 50:325-341

Grigg A (2019) Select-service brands take experiential tack. Hotel management. https://www.hotelmanag ement.net/development/select-service-brands-take-experiential-tack. Accessed 12 Aug 2020

Guo X, Ling L, Yang C, Li Z, Liang L (2013) Optimal pricing strategy based on market segmentation for service products using online reservation systems: an application to hotel rooms. Int J Hosp Manag 35:274-281

Hammond K, Ehrenberg A, Goodhardt G (1996) Market segmentation for competitive brands. Eur J Mark 30:39-49

Hang H, Aroean L, Chen Z (2020) Building emotional attachment during COVID-19. Ann Tour Res. https://doi.org/10.1016/j.annals.2020.103006

Hao F, Xiao Q, Chon K (2020) COVID-19 and China's hotel industry: impacts, a disaster management framework, and post-pandemic agenda. Int J Hosp Manag. https://doi.org/10.1016/j.ijhm.2020. 102636

Higgins SM (2006) Brands focus on worldwide growth. Hotel Motel Manag 221:30-32

Hoisington A (2019) U.S. select-service investment remains steady. Hotel management. https://www. hotelmanagement.net/transactions/u-s-select-service-investment-remains-steady. Accessed 12 Aug 2020

Huang ZJ, Cai LA (2015) Modeling consumer-based brand equity for multinational hotel brands: when hosts become guests. Tour Manag 46:431-443

Hultman M, Papadopoulou C, Oghazi P, Opoku R (2021) Branding the hotel industry: the effect of stepup versus step-down brand extensions. J Bus Res 124:560-570

Jang S, Moutinho L (2019) Do price promotions drive consumer spending on luxury hotel services? The moderating roles of room price and user-generated content. Int J Hosp Manag 78:27-35

Jeong I, Lee JH, Kim E (2019) Determinants of brand localization in International markets. Serv Bus 13:75-100

JLL (2020) During COVID-19, economy hotels lead the way in housing essential workers. JLL. https:// www.us.jll.com/en/trends-and-insights/investor/during-covid19-economy-hotels-lead-the-way-inhousing-essential-workers. Accessed 10 Aug 2020

Kang KH, Lee S (2014) The moderating role of brand diversification on the relationship between geographic diversification and firm performance in the US lodging industry. Int $\mathrm{J}$ Hosp Manag 38:106-117 
Kim WG, Han J, Hyun K (2004) Multi-stage synthetic hotel pricing. J Hosp Tour Res 28:166-185

Kim B, Kim SS, Heo CY (2016) Analysis of satisfiers and dissatisfiers in online hotel reviews on social media. Int J Contemp Hosp Manag 28:1915-1936

Kim WG, McGinley S, Choi HM, Luberto E, Li JJ (2020) How does room rate and rate dispersion in US hotels fluctuate? J Hosp Tour Manag 44:227-237

Kimes SE (1989) The basics of yield management. Cornell Hosp Q 30:14-19

Kubacki D (2019) What 2019's new brands say about guests' priorities. Hotel news now. https://hotel newsnow.com/Articles/299532/What-2019s-new-brands-say-about-guests-priorities. Accessed 11 Aug 2020

Lai IKW (2019) Hotel image and reputation on building customer loyalty: an empirical study in Macau. J Hosp Tour Manag 38:111-121

Levin Y, McGill J, Nediak M (2008) Risk in revenue management and dynamic pricing. Oper Res 56:326-343

Levy S, Duan W, Boo S (2012) An analysis of one-star online reviews and responses in the Washington, D.C. lodging market. Cornell Hosp Q 54:49-63

Lewis RC, Shoemaker S (1997) Price-sensitivity measurement: a tool for the hospitality industry. Cornell Hosp Q 38:44-54

Love AS, Walker BH, Sutton DW (2012) New option in hotel appraisals: quantifying the revenue enhancement value of hotel brands. Appr J 80:223-233

Mahasuweerachai P, Qu H (2015) The effect of multiple hotel brand extensions. Tour Hosp Res 15:27-38

Mandelbaum R (2017) Select-service hotels: efficient and profitable. Hosp net. https://www.hospitalit ynet.org/opinion/4082270.html. Accessed 29 June 2017

Manley B (2017) Hoteliers chase profits by dropping room service. CoStar. https://www.costar.com/artic le/1039699371. Accessed 30 Aug 2020

Martínez E, De Chernatony L (2004) The effect of brand extension strategies upon brand image. J Consum Mark 21:39-50

Mathies C, Gudergan SP (2012) Do status levels in loyalty programs change customers' willingness to pay? J Rev Pric Manag 11:274-288

Mattimoe R, Seal W (2011) Pricing in a service sector context: accounting and marketing logics in the hotel industry. Eur Acc Review 20:355-388

McMullen-Coyne S (2004) Selecting the right mixed-use elements critical to success. Hotel Motel Manag 219:54-55

Medina K (2017) Select-service hotels continue to drive transactions market. Hotel management. http:// www.hotelmanagement.net/financing/limited-service-adaptive-re-use-buoy-a-transactions-marketplagued-by-political. Accessed 9 Jul 2017

Mogelonsky L (2015) The battle between full-service and limited-service properties. Hosp net. https:// www.hospitalitynet.org/opinion/4072976.html. Accessed 20 Dec 2017.

Noone BM, McGuire KA (2016) Impact of attitudinal loyalty on the frequent unmanaged business traveler's use of price and consumer reviews in hotel choice. J Rev Pric Manag 15:20-36

O'Neill JW, Xiao Q (2006) The role of brand affiliation in hotel market value. Cornell Hosp Q 47:210-223

Pan CM (2007) Market demand variations, room capacity, and optimal hotel room rates. Int J Hosp Manag 26:748-753

Piercy NF, Cravens DW, Lane N (2010) Thinking strategically about pricing decisions. J Bus Strat 31:38-48

Rahimi R, Kozak M (2017) Impact of customer relationship management on customer satisfaction: the case of a budget hotel chain. J Travel Tour Mark 34:40-51

Rhee HT, Yang SB (2015) Does hotel attribute importance differ by hotel? Focusing on hotel star-classifications and customers' overall ratings. Comp Hum Behav 50:576-587

Roper A, Carmouche R (1989) Budget hotels: a case of mistaken identity? Int J Contemp Hosp Manag $1: 25-31$

Rosli N, Che-Ha N, Ghazali EM (2020) The influence of hotel attributes on brand attachment and postconsumption outcomes: the mediating effects of brand credibility. Int J Bus Soc 21:313-333

Schooley T (2013) Full-service hotels vs. limited service hotels. Pittsburgh business times. https://www. bizjournals.com/pittsburgh/blog/the-next-move/2013/07/full-service-hotels-versus-limited.html. Accessed 11 Aug 2020

Sharp BM (1993) Managing brand extension. J Consum Mark 10:11-17 
Smith W (1956) Product differentiation and market segmentation as alternative marketing strategies. J Mark 21:3-8

Steed E, Gu Z (2005) An examination of hotel room pricing methods: practiced and proposed. J Rev Pric Manag 3:369-379

STR (2018) STR chain scale. HospialityNet. https://www.hotelnewsnow.com/Media/Default/Images/ chainscales.pdf. Accessed 8 Aug 2021

Su N, Reynolds D (2019) Categorical differences of hotel brand personality. Int J Contemp Hosp Manag 31:1801-1818

Tanford S, Raab C, Kim Y (2012) Determinants of customer loyalty and purchasing behavior for fullservice and limited-service hotels. Int J Hosp Manag 31:319-328

Timmermann M (2019) The best and worst hotel chains in America. Clark. https://clark.com/travel/hotelchains-best-worst-america. Accessed 10 Aug 2020

Ting D (2016) Big hotel chains ditch full-service properties in favor of the light-touch approach. Skift. https://skift.com/2016/08/16/big-hotel-chains-ditch-full-service-properties-in-favor-of-the-lighttouch-approach. Accessed 16 Aug 2020

Uncles M, Kennedy R, Nenycz-Thiel M, Singh J, Kwok S (2012) In 25 years, across 50 categories, user profiles for directly competing brands seldom differ. J Advert Res 52:252-261

Van Stekelenburg M, Sankaran K, Hartley A, Gonzalez V (2020) A look at COVID-19's potential impact on hotel expense ratios. Hotel management. https://www.hotelmanagement.net/operate/covid-19-spotential-impact-hotel-expense-ratios. Accessed 16 Aug 2020

Wang X, Sun J, Wen H (2019) Tourism seasonality, online user rating and hotel price: a quantitative approach based on the hedonic price model. Int J Hosp Manag 79:140-147

Wind J, Green PE, Shifflet D, Scarbrough M (1989) Courtyard by Marriott: designing a hotel facility with consumer-based marketing models. Interfaces 19:25-47

Wroten B (2020) Pressures of pandemic slow California hotel pipeline. Hotel news now. https://hotel newsnow.com/Articles/304224/Pressures-of-pandemic-slow-California-hotel-pipeline. Accessed 1 Sept 2020

Xia H, Vu HQ, Law R, Li G (2020) Evaluation of hotel brand competitiveness based on hotel features ratings. Int J Hosp Manag. https://doi.org/10.1016/j.ijhm.2019.102366

Xie KL, Kwok L (2017) The effects of Airbnb's price positioning on hotel performance. Int J Hosp Manag 67:174-184

Yapp G (2015) Full services vs. limited services hotels. USA Today. http://traveltips.usatoday.com/fulls ervice-vs-limitedservice-hotels-106136.html. Accessed 16 Aug 2020

Zhang Z, Ye Q, Law R (2011) Determinants of hotel room price. Manage 23:972-981

Publisher's Note Springer Nature remains neutral with regard to jurisdictional claims in published maps and institutional affiliations. 